\title{
Operatīvās darbības tiesiskā regulējuma problēmas
}

\author{
Dr. iur. Aleksandrs Matvejevs \\ Daugavpils Universitāte, Sociālo zinātnu fakultāte, \\ Tiesību katedra, Latvija \\ aleksandrsmatvejevs5@inbox.lv
}

\section{Kopsavilkums}

Operatīvās darbības likums Latvijā stājās spēkā 1994. gada 13. janvārī. Kopš tā laika operatīvās darbības tiesiskā regulējuma nepilnības raisa Latvijas tiesību zinātnieku un praktiku diskusijas.

Problēmu jautājumi, kas saistīti ar operatīvās darbības tiesiskā regulējuma piemērošanu, faktiski tiek risināti, veicot izmaiņas Operatīvās darbības likumā. Netiek skatīti jautājumi par Kriminālās izlūkošanas likuma izstrādi. Raksta mērḳis ir veicināt diskusiju par jauna likuma izstrādes nepieciešamību.

Atslēgvārdi: operatīvā darbība, kriminālā izlūkošana, operatīvās darbības subjekti, Operatīvās darbības likums.

\section{levads}

Profesors Ivans Vedins norāda, ka zinātniskā problēma ir pētniecības jautājums, uz kuru esošajā zināšanu sistēmā netiek gūta atbilde. Lìdz ar to jēdzienu "jautājums", "pētnieciskais jautājums" un "zinātniskā problēma" attiecības atbilst logiskai attiecībai no plašākā uz šaurāko. Zinātniskās problēmas būtību var izprast kā savdabīgu zināšanu paveidu - tās ir zināšanas par nezināšanu. Šāds škietami pretrunīgs formulējums izsaka reālu izziṇas procesa pretrunu starp vēsturiski ierobežotām esošām zināšanām un izziņas procesa bezgalību. Tieši šãdā nozīmē problēma ir viena no svarīgākajām zinātniskās izziñas formām izziṇas attīstības procesā [17].

Lai veiktu pētījumu, ir nepieciešams apzināt, kāda problēma pastāv pētniecības jautājumā. Viens no aspektiem, kas norāda uz pētāmās problēmas jautājuma aktualitāti, ir tas, ka Operatīvās darbības likuma 25. pants nav grozìts kopš tā spēkā stāšanās briža 
un tas nosaka vispārīgi operatīvās darbības subjektu sistēmu Latvijā. Turklāt nav sākta diskusija par Kriminālās izlūkošanas likuma izstrādi.

Pētỉjuma mērḳis - izpētìt operatīvās tiesiskās darbības problēmas, kuras saistītas ar operatīvās darbības subjektu tiesisko regulējumu.

Materiāls un metodes - normatīvo aktu analīze un apraksts. Ar deduktīvās metodes palīdzību autors izdara secinājumus par operatīvās darbības subjektu tiesisko regulējumu, balstoties uz pētījumā izdarìtajiem secinājumiem un teorētiskajām atziṇām.

\section{Rezultāti}

Problēmu jautājumi, kas saistīti ar operatīvās darbības tiesiskā regulējuma piemērošanu, faktiski tiek risināti, veicot izmaiṇas Operatīvās darbības likumā. Netiek skatīti jautājumi par Kriminālās izlūkošanas likuma izstrādi.

\section{Diskusija}

Latvijas Republikas Saeima Operatīvās darbības likumu pieñēma 1993. gada 16. decembrī [12]. Operatīvās darbības likums pirmo reizi Latvijas pastāvēšanas vēsturē reglamentēja operatīvās darbības. Tādējādi iedzīvotāji uzzināja, kas ir operatīvā darbība, kā tā tiek veikta, tās tiesiskos pamatus, principus, uzdevumus, mērķus un saturu, procesu, formas un veidus, operatīvās darbības subjektu amatpersonu statusu, tiesības, pienākumus un atbildību, kā arī šìs darbības finansēšanu, uzraudzību un kontroli.

Pirmās brīvvalsts un Latvijas Padomju Sociālistiskās Republikas laikā operatīvās darbības jomu regulēja attiecīgo valsts institūciju izstrādātās instrukcijas, nolikumi un citi iekšējie normatīvie akti. Tiem bija sevišḳi slepena dokumenta statuss, tāpēc tie bija pieejami tikai attiecīgu institūciju darbiniekiem.

No Operatīvās darbības likuma pieṇemšanas brī̌̌a tajā ir veikti 12 grozījumi. Pēdējie grozịjumi stājās spēkā 2016. gada 1. augustā [2]. Grozỉjumu svarīgākais mērkis ir nodrošināt, lai tiktu garantēta cilvēktiesību ievērošana operatīvās darbības procesā.

Lìdz šim brīdim nav veikti grozījumi, kuri saistīti ar operatīvās darbỉbas subjektu noteikšanu. Operatīvās darbības likumā ir vispārīgi noteikta operatīvās darbības subjektu sistēma. Likuma 25. panta pirmajā daḷā noteikts, ka operatīvās darbības subjektu sistēmu veido valsts drošības, aizsardzības un sabiedriskās kārtības nodrošināšanas iestādes.

Valsts drošības iestāžu likuma [14] 11. panta pirmajā dạ̦ā noteikts, ka Valsts drošības iestāžu kopumu veido Satversmes aizsardzības birojs, Militārās izlūkošanas un drošības dienests un Drošības policija. No likuma izriet, ka Valsts policija nav valsts drošibas iestāde.

Likumā "Par policiju" [11] nav minēta tāda iestāde kā sabiedriskās kārtības nodrošināšanas iestāde. Ši likuma 15. pantā bija noteikts, ka likuma III nodaḷā paredzētās pilnvaras ir tiesīga pildìt tikai policija un citas Ministru kabinetam pakḷautās kārtības 
sargāšanas institūcijas likumā noteiktajā kārtībā, jo tika gatavoti priekšlikumi par robežsardzes un muitas dienestu veidošanu. Šis teikums 1999. gada 15. maijā no likuma 15. panta tika svïtrots [3]. Likuma "Par policiju" 15. pantā noteikts, ka policija sastāv no Valsts policijas, Drošỉbas policijas, pašvaldības policijas un ostas policijas.

Turpretī Operatīvās darbības likuma 25. panta pirmajā daḷā noteikts, ka ir citas ìpaši pilnvarotas valsts institūcijas, kurām ar likumu ir piešḳirtas tiesības atbilstīgi kompetencei veikt operatīvās darbības pasākumus. No likuma izriet, ka Valsts policijai ir nepieciešams operatīvās darbības subjekta īpašs pilnvarojums. No likuma "Par policiju" normām izriet, ka Valsts policijai nav operatīvās darbības subjekta īpaša pilnvarojuma, bet policijas darbiniekiem ir noteikti pienākumi un tiesības veikt operatīvās darbības pasākumus.

Salīdzinot likumu "Par policiju" ar Iekšējās drošības biroja likumu [5], var konstatēt, ka Iekšējās drošības biroja likuma 2. panta trešajā dạ̣ā ir noteikts, ka birojs ir operatīvās darbības subjekts un izmeklēšanas iestāde. Jāṇem vērā, ka Iekšējās drošības biroja likums regulē vienas iestādes darbību, bet likums "Par policiju" regulē vairāku policijas iestāžu darbību. Turklāt jāṇem vērā, ka Valsts drošîbas iestāžu likuma 15. panta piektajā daḷā noteikts, ka Drošības policija ir operatīvās darbības subjekts.

Likuma "Par policiju" 10. panta ceturtajā daḷā noteikts, ka saskaṇā ar policijas uzdevumiem policijas darbinieka pamatpienākumi atbilstīgi dienesta kompetencei ir saskaṇā ar likuma prasībām veikt izmeklēšanu, nodrošināt noteiktajā kārtībā kriminālistikas speciālistu piedalīšanos izmeklēšanas darbībās, veikt nepieciešamos operatīvās meklēšanas un citus likumā noteiktos pasākumus, lai atklātu, pārtrauktu un novērstu noziedzīgus nodarïjumus, konstatētu un meklētu personas, kuras tos izdarïjušas vai kuras slēpjas no izmeklēšanas un tiesas, izvairās no kriminālsoda izciešanas vai ir bezvēsts prombūtnē, kã arī lai konstatētu cilvēku personību un identificētu līḳus. Savukārt 12. panta pirmās daḷas 22. punktā noteikts, ka policijas darbiniekam, pildot viņam uzliktos pienākumus atbilstīgi dienesta kompetencei, lai savlaicīgi novērstu un atklātu noziedzīgus nodarījumus un meklētu personas, ir tiesības veikt operatīvās meklēšanas pasākumus likumā noteiktajos gadījumos un kārtībā, arī iesaistot personas slepenā sadarbībā. Iepriekšminētie panti nav grozìti un papildināti atbilstīgi veiktajiem grozījumiem Operatīvās darbības likumā.

Likumā "Par policiju" nav noteikta Valsts policijas dienestu kompetence. Vārda "kompetence" nozīme latviešu valodā ir tiesības (kādā jautājumā), pilnvaru apjoms [8]. Savukārt juridisko terminu vārdnīcā tas tiek skaidrots kā valsts iestādes un amatpersonas tiesību un pienākumu kopums [6].

2006. gada 15. jūnijā no likuma "Par policiju" tika svìtrots 17., 18. un 20. pants, kas Valsts policijas struktūru padarīja iedzīvotājiem neizprotamu, pamatojot grozījumu nepieciešamību ar to, ka Valsts policijas struktūra saskaṇā ar Valsts pārvaldes iekārtas likumu tiek atspoguḷota iestādes nolikumā un reglamentā [3].

Valsts policijas nolikumā [16] ir norādīts, ka Valsts policiju vada Valsts policijas priekšnieks. Valsts policijas priekšnieks veic Valsts pārvaldes iekārtas likumā noteiktās tiešās pārvaldes iestādes vadītāja funkcijas. Valsts policijas struktūru un darba organizāciju 
nosaka Valsts policijas reglamentā. Ministru kabineta izdotais Valsts policijas nolikums ir ārējais normatīvais akts, savukārt Valsts policijas reglaments ir iekšējais normatīvais akts. Valsts pārvaldes iekārtas likuma [15] 72. panta ceturtajā daḷā noteikts, ka iekšejais normatīvais akts ir saistošs iestādei (tās struktūrvienībai, darbiniekiem) vai amatpersonām, attiecībā uz kurām tas izdots.

Autors uzskata, ka nepamatoti no likuma "Par policiju" tika svitrots 17. un 18. pants, kuri noteica gan Kārtības policijas, gan arī Kriminālpolicijas kompetenci, jo iekšējais normatīvais akts (reglaments) nevar aizskart trešās personas intereses, jo ir saistošs iestādei (tās struktūrvienībai, darbiniekiem) vai amatpersonām, attiecībā uz kurām tas izdots.

Jāṇem vērā, ka policijas darbības, tostarp operatīvās darbības, pasākumi skar cilvēka pamattiesības un tās var ierobežot tikai ar likumu. Latvijas Republikas Satversmes [9] 96. pants garantē ikviena cilvēka tiesības uz privātās dzīves, mājokḷa un korespondences neaizskaramību. Latvijas Republikas Satversmes 116. pantā noteikts, ka šīs tiesības var ierobežot likumā paredzētajos gadījumos, lai aizsargātu citu cilvēku tiesības, demokrātisko valsts iekārtu, sabiedrības drošību, labklājību un tikumību. Šīs tiesības vēl plašāk ir noteiktas Eiropas Cilvēktiesību un pamatbrīvību aizsardzības konvencijā, kura Latvijā ir spēkā kopš 1997. gada 27. jūnija [1]. Tā, piemēram, Eiropas Cilvēktiesību un pamatbrīvību aizsardzības konvencijas 8. panta 2. punktā noteikts, ka valsts institūcijas nedrīkst nevienam traucēt baudīt šìs tiesības, izṇemot gadỉjumos, kas paredzēti likumā un ir nepieciešami demokrātiskā sabiedrībā, lai aizstāvētu valsts drošības, sabiedriskās kārtības vai valsts labklājỉbas intereses, lai nepięlautu nekārtības vai noziegumus, lai aizsargātu veselību vai morāli vai lai aizstāvētu citu tiesības un brīvības.

Salïdzinot Latvijas Republikas un Lietuvas Republikas likumus, var konstatēt, ka Lietuvas Republikā ir pieṇemts Kriminālās izlūkošanas likums, kurš stājās spēkā 2013. gada 1. janvārī [10]. Vienlaikus ar šì likuma stāšanos spēkā ir zaudējis spēku Lietuvas Republikas Operatīvās darbības likums. Pieṇemtais Lietuvas Republikas Kriminālās izlūkošanas likums reglamentē kriminālās izlūkošanas pamatus, tās subjektu tiesības un pienākumus, izmeklēšanas veikšanu, finansēšanu, koordinēšanu un kontroli, kā arī personu piedalīšanos kriminālajā izlūkošanā un izlūkošanas informācijas izmantošanu. Likums precīzi regulē kriminālās izlūkošanas darbību jēdzienus, veidus un instrumentus, informācijas vākšanas metodes, tās izmantošanu, aizsardzību un atbildību par nesankcionētu lietošanu; likumā arī nodalīta tiesībsargājošo iestāžu darbība noziedzīgu nodarījumu izmeklēšanā, t. i., kriminālā izlūkošana nodalīta no izlūkošanas un pretizlūkošanas [13].

Lietuvas Republikas Kriminālās izlūkošanas likuma 2. panta vienpadsmitajā daḷā ir noteiktas kriminālās izlūkošanas institūcijas, kuras realizē kriminālās izlūkošanas informācijas vākšanu, un šîs darbības metodes [10].

Salīdzinot Operatīvās darbības likuma un Kriminālprocesa likuma [7] normas, var konstatēt, ka Kriminālprocesa likuma 386. pantā (redakcijā, kas stājās spēkā 2018. gada 1. janvārī) ir precīzi noteiktas izmeklēšanas iestādes. Izmeklēšanu atbilstīgi kompetencei veic: Valsts policija, Drošỉbas policija, Valsts ien̦ēmumu dienesta Iekšējās drošības pārvalde, Militārā policija, Ieslodzijuma vietu pārvalde, Korupcijas novēršanas un apkarošanas birojs, 
Valsts ieņēmumu dienesta Nodokḷu un muitas policija, Valsts robežsardze, tālbraucienos esošu jūras kuğu kapteiṇi, ārvalsts teritorijā esošas Latvijas Nacionālo bruṇoto spēku vienības komandieris, Iekšējās drošības birojs.

\section{Secinājumi un priekšlikumi}

Operatīvās darbības likuma 25. pantu ir nepieciešams precizēt šādā redakcijā: "Operatīvās darbības subjektu sistēmu veido: Valsts policija, Valsts ienēemumu dienesta Iekšējās drošības pārvalde, Militārā policija, Ieslodzījuma vietu pārvalde, Korupcijas novēršanas un apkarošanas birojs, Valsts ieñēmumu dienesta Nodokḷu un muitas policija, Iekšējās drošības birojs, Satversmes aizsardzības birojs, Drošîbas policija, Militārās izlūkošanas un drošības dienests."

Likumā "Par policiju" nepieciešams noteikt gan Kārtības policijas, gan Kriminālpolicijas kompetenci, jo iekšējais normatīvais akts (reglaments) nevar aizskart trešās personas intereses. Jāṇem vērā, ka policijas darbības, tostarp operatīvās darbības, pasākumi skar cilvēka pamattiesības un tās var ierobežot tikai ar likumu.

Turklāt, ņemot vērā Lietuvas Republikas Kriminālās izlūkošanas likumu un citu Eiropas valstu tiesību aktus, būtu jāraisa diskusija par Latvijas Republikas Kriminālās izlūkošanas likuma izstrādes nepieciešamību.

\section{Problems of Investigative Operations Regulation}

\section{Abstract}

An investigative operations regulatory gap for several years has been raising the discussion among Latvian legal scholars and practitioners alike. The Investigative Operations Law entered into force on 13 January, 1994.

The current article leads to the conclusion that problem issues related to investigative operations of legal framework for the application is actually being addressed through changes in the Investigative Operations Law. However, the article does not deal with questions about the new law of criminal intelligence development.

Keywords: investigative operations, criminal intelligence, body performing investigative operations, Investigative Operations Law.

\section{Literatūra}

1. Eiropas Cilvēktiesību un pamatbrīvību aizsardzības konvencija: Starptautiskais dokuments. Latvijas Vèstnesis. 143/144 (858/859), 13.06.1997.

2. Grozījumi Operatīvās darbības likumā. 10.03.2016. likums. Latvijas Vēstnesis. 57 (5629), 22.03.2016. Stājās spēkā 01.08.2016. 
3. Grozījumi likumā "Par policiju”. 13.95.1999. likums. Latvijas Vēstnesis. 171/172 (1631/1632), 26.05.1999. Stājās spēkā 01.07.1999.

4. Grozījumi likumā "Par policiju”. 13.05.2006. likums. Latvijas Vēstnesis. 98 (3466), 27.06.2006. Stājās spēkā 01.10.2006.

5. Iekšējās drošības biroja likums. 17.12.2014. likums. Latvijas Vēstnesis. 257 (5317), 30.12.2014. (pamatredakcija). Stājās spēkā 11.11.2015. Iegūts no: https://likumi.lv/ta/id/271327-ieksejasdrosibas-biroja-likums [sk. 20.03.2017.].

6. Juridisko terminu vārdnīca. Rīga: Nordik, 1998, 111. lpp.

7. Kriminālprocesa likums. 21.04.2005. likums. Latvijas Vēstnesis. 74 (3232), 11.05.2005. (pamatredakcija). Stājās spēkā 01.10.2005. Iegūts no: https://likumi.lv/doc.php?id=107820 [sk. 20.03.2017.].

8. Latviešu valodas vārdnīca. 30000 pamatvārdu un to skaidrojumi. Rīga: Avots, 2006, 524.

9. Latvijas Republikas Satversme. 15.02.1922. likums. Latvijas Vēstnesis. 43, 01.07.1993. (pamatredakcija). Stājās spēkā 07.11.1922. Iegūts no: https://likumi.lv/doc.php?id=57980 [sk. 20.03.2017.].

10. Lietuvos Respublikos kriminalinès žvalgybos įstatymas. $2012 \mathrm{~m}$. spalio $2 \mathrm{~d}$. Nr. XI2234. Iegūts no: http://www3.lrs.lt/pls/inter3/dokpaieska.showdoc_l?p_id=437554- [sk. 20.03.2017.].

11. Likums "Par policiju”. 04.06.1991. likums. Ziṇotājs. 31/32, 15.08.1991. (pamatredakcija). Stājās spēkā 04.06.1991. Iegūts no: https://likumi.lv/doc.php?id=67957 [sk. 20.03.2017.].

12. Operatīvās darbības likums. 16.12.1993. likums. Latvijas Vēstnesis. 131, 30.12.1993. (pamatredakcija). Stājās spēkā 13.01.1994. Iegūts no: https://likumi.lv/doc.php?id=57573 [sk. 20.03.2017.].

13. Tumalavičus, V. Drošības jautājumi: mūsdienu tendences Lietuvas tiesību aizsardzības sistēmā. Socrates: Rīgas Stradina universitātes Juridiskās fakultātes elektroniskais juridisko zinātnisko rakstu žurnāls. Rīga: RSU, 2015, Nr. 3(3). Iegūts no: http://www.rsu.lv/images/stories/dokumenti/ publikacijas/socrates_3_2015.pdf [sk. 20.03.2017.].

14. Valsts drošỉbas iestāžu likums. 05.05.1994. likums. Latvijas Vēstnesis. 59 (190), 19.09.1994. (pamatredakcija). Stājās spēkā 19.05.1994. Iegūts no: https://likumi.lv/doc.php?id=57256 [sk. 20.03.2017.].

15. Valsts pārvaldes iekārtas likums. 06.06.2002. likums. Latvijas Vēstnesis. 94 (2669), 21.06.2002. (pamatredakcija). Stājās spēkā 01.01.2003. Iegūts no: https://likumi.lv/doc.php?id=63545 [sk. 20.03.2017.].

16. Valsts policijas nolikums. 18.01.2005. noteikumi Nr. 46. Latvijas Vēstnesis. 12 (3170), 21.01.2005. (pamatredakcija). Stājās spēkā 22.01.2005. Iegūts no: https://likumi.lv/doc.php?id=99940 [sk. 20.03.2017.].

17. Vedins, I. Zinātne un patiesība. Rīga: Avots, 2008, 113.-114. 